\title{
Freight Car Bogie Properties Analysis by Means of Simulation Computations
}

Tomas Lack, Juraj Gerlici, Maria Manurova

Faculty of Mechanical Engineering, Department of Transport and Handling Machines, University of Zilina. Univerzitná 8215/1, 01026 Zilina. Slovak Republic. E-mail: tomas.lack@fstroj.uniza.sk, juraj.gerlici@fstroj.uniza.sk, maria.manurova@fstroj.uniza.sk

The article deals with the results of the simulation analysis of a railway wagon bogie model. We analysed four freight wagon bogie variants for its dynamics properties research. The bogie models correspond in general to the Y25 bogie concept. The models were created in SIMPACK software enhanced by the RAIL module. From the research results depicted in the graphs we found out, that the newly designed bogie variant gives the best results when compared to the other analysed versions. The newly designed model consists of a standard Y25 bogie frame with two Lenoire friction dampers. This bogie is equipped with longitudinal linkages on both sides. These linkages are completed with a radial torsion binding, torsion rod, between side bogie parts. The contact of railway wheels and rails generates active forces affecting the surface contact, affecting the size of the normal and tangential stress, wear surfaces of the wheel/rail, or directly the size of the derailment.

Keywords: Chassis, Lenoir, Damper, Coupling, Simulation

\section{Acknowledgement}

This paper was created during the processing of the project "RAILBCOT - RAIL Vehicles Brake COmponents Test Stand", ITMS Code 26220220011 based on the support of Research and Development Operational Program financed by European Fund of a Regional Development. The work was also supported by the Scientific Grant Agency of the Ministry of Education of the Slovak Republic in project No. APVV-0842-11: "Equivalent railway operation load simulator on the roller rig.

\section{Research-Educational Center of Rail Vehicles (VVCKV)}

\section{References}

[1] IWNICKI, S., BEZIN, Y., ORLOVA, A., JOHNSSON, P.-A., STICHEL, S., SCHELLE, H. (2013). The 'SUSTRAIL' High Speed Freight Vehicle: Simulation of Novel Running Gear Design. Proc. of the 23rd Intern. Symposium on Dynamics of Vehicles on Roads and Tracks, p. 11. IAVSD. August 2013 Qingdao, China.

[2] LACK, T., GERLICI, J. (2014) Modified HHT method for vehicle vibration analysis in time domain utilisation. Applied mechanics and materials. - ISSN 1660-9336. - Vol. 486 (2014), s. 396-405.

[3] LACK, T., GERLICI, J., MAŇUROVA, M. (2014). Analysis of Dynamic Properties of Freight Bogie Model 1 (In Slovak), Innovations in the concept, design, manufacturing and testing of freight II: January 2015, Zilina: University of Zilina, ISBN 978-80-554-0955-9. S. 65-74.

[4] LACK, T., GERLICI, J., MAŇUROVA, M. (2015). Analysis of Dynamic Properties of Freight Bogie Model 2 (In Slovak), Innovations in the concept, design, manufacturing and testing of freight II: January 2015, Zilina: University of Zilina, ISBN 978-80-554-0980-1. S. 51-56.

[5] DIŽO, J., HARUŠINEC, J., BLATNICKÝ, M. (2015) Multibody System of a Rail Vehicle Bogie with a Flexible Body. Manufacturing Technology: Journal for Science, Research and Production. - ISSN 1213-2489. - Vol. 15, no. 5 (2015), pp. 781-788.

[6] DIŽO, J., (2015) Evaluation of Ride Comfort for Passengers by Means of Computer Simulation. Manufacturing Technology: Journal for Science, Research and Production. - ISSN 1213-2489. - Vol. 15, no. 1 (2015), pp. 8-14.

[7] DIŽO, J., BLATNICKÝ, M., SKOČILASOVÁ, B. (2015) Computational Modelling of the Rail Vehicle Multibody System Including Flexible Bodies. Communications: scientific letters of the University of Žilina. - ISSN 1335-4205. - Vol. 17, no. 3 (2015), pp. 31-36.

[8] LACK, T., GERLICI, J. (2015). Freight Car Bogie Analysis by Means of Simulation Computations (In Slovak), PRORAIL 2015 Current problems in rail vehicles, $22^{\text {nd }}$ intern. conference, Zilina, September 2015. ISBN 978-8089276-48-6.

[9] LACK, T., GERLICI, J. (2015). Railway Bogie Properties Analysis by Means of Simulation Computations (In Slovak). Railway transport and logistics. ISSN 1336-7943. - Vol. 11, č. 2 (2015), online, pp. 54-60. 
[10] MAŇUROVÁ, M., SUCHÁNEK, A. (2016). Determination of Stiffess of Triple Spring Built in a Bogie of a Rail Vehicle. Manufacturing Technology: Journal for science, research and production. Univerzita J. E. Purkyně in Ústí n. Labem. April 2016, Vol. 16, No. 2 Pp. 390 - 396. ISSN 1213-2489.

[11] ŠŤASTNIAK, P. GERLICI, J., LACK, T., HARUŠINEC, J. (2013)., Computer aided simulation analysis for computation of modal analysis of the freight wagon TRANSCOM 2013 : 10-th European conference of young researchers and scientists : Žilina, June 24-26, 2013, Slovak Republic. Section 6: Machines and equipment. Applied mechanics. - Žilina: University of Žilina, 2013. - ISBN 978-80-554-0695-4. - S. 297-300.

[12] NANGOLO, F., SOUKUP, J. (2014). The Effect of Asymmetry on Vertical Dynamic Response of Railway Vehicles. In: Manufacturing Technology: Journal for science, research and production. Univerzita J. E. Purkyně in Ústí n. Labem. October 2014, Vol. 14, No. 3 Pp. 375-380. ISSN 1213-2489.

[13] SVOBODA, M., SOUKUP, J. (2013). Dynamic measurement of four-axle railway wagon. In: Manufacturing Technology. 2013, vol. 13, iss. 4, (pp. 552-558). ISSN 1213-2489.

[14] SKOČILAS, J., SKOČILASOVÁ, B., SOUKUP, J. Determination of the rheological properties of thin plate under transient vibration. Latin American Journal of Solids and Structures. Brasil society for mechanics and engineering. ISSN 1679-7817 (print), 1679-7825 (online).

Copyright (C) 2016. Published by Manufacturing Technology. All rights reserved. 